\section{Canadian Federal Spending Powers: The Impact on Health Care Delivery}

Julie Nguyen

University of British Columbia

\section{Introduction}

National public health care has increasingly become a politically contentious concern for Canadian citizens since its establishment. The role of Canadian federalism and intergovernmental relations has been a major contributor to the controversy surrounding the funding, the development, and the outcome of health care policy. While federalism has been attributed to the expansion of health care in Canada, it has also been criticized for lacking efficiency and harbouring intergovernmental power struggles. Although the Constitution Act of 1867 outlines that provinces are responsible for health care in their jurisdiction, in practice there is actually an unclear division of powers between the two levels of government (Maioni 2002). Health care is an industry that is constantly transforming, but the framework of Canadian federalism is not proficient enough to keep up with these much needed changes. As a result, citizens may not be receiving the best health care available, and are caught in the tug of war between the provinces and the federal government.

In this paper, I argue that federal spending powers are intervening in provincial jurisdictions, through policies like the Canada Health Act (CHA) and the Established Programs Financing Act (EPF), and limiting provincial experimentation for innovative health care delivery. The federal framework is hindering interprovincial diversity and the provincial autonomy that essentially founded Canadian public health care. In the following sections, I will focus on Canadian intergovernmental relations and its effect on Medicare in terms of fiscal federalism, efficiency of policymaking, and the impact on citizens. Moreover, I will also address the future of health care in Canada with respect to federalism.

\section{Origin of Public Health Care in Canada}

The prevalence for national health insurance system and government intervention did not arise until the Second World War and the Great Depression, when Canadian citizens were severely devastated by social and economic fragility
(Bakvis, Baier and Brown 2009). Since the Second World War, the federal government played a more expansive role to develop social welfare. During the late 1940s, the province of Saskatchewan was able to successfully introduce the first model of public healthcare to its citizens through the Saskatchewan Hospitalization Act, a hospital insurance program (Wong 2005). Subsequently, this inspired the diffusion of public healthcare to other provinces in which the federal government played a key role as "a catalyst, convener and negotiator in federal-provincial cooperative efforts in health care", according to Maioni (2002). Accordingly, the federal government introduced the Hospital Insurance and Diagnostic Services Act (HIDS) in 1957, and the Medical Care Insurance Act (Medicare) in 1966. These laws mandated that the federal government would subsidize $50 \%$ of provincial health expenditures through direct cash transfers, and that each province must adopt a health insurance policy by 1971 (Bakvis and Skogstad 2008, Wong 2005). The decentralized federal state encouraged the national expansion of health care, since provinces could experiment with policies while receiving federal support. This period of Canadian federalism has been called "Co-Operative Federalism", as it is comprised of harmonious intergovernmental relationships, shared-cost federalism and flexible federal spending powers (Maioni 2002, Wong 2005).

\section{Federal and Provincial Roles in Health Care}

Canada is a relatively decentralized federal state that grants sovereignty to both orders of government within their respective jurisdictions. According to the Constitutional Act of 1867 (CA 1867), subsection 92(7) states that provinces are primarily responsible for health care and obtain the authorization to legislate in regards to the "Establishment, maintenance and management of hospitals, asylums and charities [excluding marine hospitals]". Moreover, section 92(16) also grants the provincial government jurisdiction over "Generally all matters of a merely local or private nature in the province" (Bakvis and Skogstad 2008, Rocher and Smith 2002). While the federal government does not have a direct role in the matters of health care, they do have constitutional responsibilities outlined in Section 91(1) in regards to public health and the general welfare of people in the territories and under special classes. Moreover, Section 91(3) states that the federal government obtains the ability to "[raise] money by any mode or system of taxation". Consequently, Ottawa has increasingly taken advantage of this by using its federal spending powers to gain political leverage, thus shaping policies in the realm of health care (Wong 2005) 
In actuality, the provinces and territories are so politically, sociologically, and geographically diverse that Canada does not have a true national public health care system. Instead, Medicare is comprised of an amalgamation of 13 unique models of provincial and territorial health policies that are unified by overarching federal principles of Canadian health standards formed by the federal government (Wong 2005). Given the realities of the complexity of health care, the division of powers outlined in the CA 1867 are still ambiguous; and there will certainly be many federal-provincial jurisdictional overlaps. It is these unassigned, fluid responsibilities, that have been arenas of major political contestation and power struggles. Moreover, the unclear lines of responsibility lower the efficiency and promptness of health care provision to citizens.

\section{Fiscal Federalism}

The funding for Canadian health care is overseen by the two primary levels of government, federal and provincial, in a relationship called fiscal federalism. Fiscal federalism in health policy refers to the intergovernmental processes of taxation and expenditures that allow the provinces to adequately fulfill their constitutional requirement of health care delivery. This process is mainly carried out through the allocation of funds via federal spending powers, which is generally the national government's principal method of health care involvement. Federal spending powers include two kinds of payment schemes: cash payments (typically shared cost programs and block grants) and tax points (Maioni 2002).

\section{Federal Spending Powers}

During the establishment of health care, the federal spending powers were predominantly presented through 50:50 shared cost programs of the 1958 HIDS Act and the 1967 Medical Care Insurance Act. However, the federal government was not able to control their expenditures through the cost-sharing formula and, in turn, replaced that scheme with the EPF Act in 1977. The EPF Act reduced Ottawa's commitment to match provincial health expenditures, implementing block grants and permanent transfers of tax points; thus, allowing provinces to directly collect a percentage of federal tax revenues. Initially, the provinces saw this act as a means of increasing political autonomy and acquiring financial independence through greater taxation powers, as well as reducing federal oversight on health policies. Unfortunately, the EPF short-changed the provinces and there were major disparities in health care funding. Health care costs were rising above the rate of inflation and
GDP growth, which placed immense fiscal pressures on the provincial governments (Jordan 2009, Wong 2005). As a result, many provinces resorted to charging user fees and increased privatization which, as Jordan (2009) states, "was a move that threatened the integrity of Medicare".

The federal government was, indeed, losing grip over the health system and implemented the Canada Health Act (CHA) in 1984 to counteract the balance of powers. Essentially, the CHA re-established the federal role in health care and asserted five national standards from the Medical Care: universality, accessibility, comprehensiveness, portability, and public administration (Maioni 2002). The key aspects of the CHA are the financial penalties incurred on provinces that failed to meet the CHA requirements, and the guise that provinces would have more independence to make health care decisions (Johnson Redden 2002, Jordan 2009, Wong 2005). While the CHA strives to improve health care delivery through national norms like portability of health care and the prohibition of user-fees, the act actually undermines provincially policymaking (Fierlbeck 2002). The provinces are bound to national health care standards and are forced to expend resources on federal laws, thus taking away their liberty to allot those funds to innovative provincial health policies. Wong (2005) states that the CHA is "a straightjacket on provincial and territorial health policymakers" as the financial sanctions go against the principles of the Constitution. The CHA insists on the maintenance of national standards, but provides less funding than ever before. If similar levels of service were required across Canada, it would be necessary for the federal government to pay for it. To make matters worse, in 1989-1990 the EPF funds were scaled back and frozen, leaving provinces with less federal financial support (Maioni 2002). The CHA and lack of EPF funds caused extreme intergovernmental tensions, as the provinces were required to meet $\mathrm{CHA}$ standards with meagre financial resources.

During the mid-1990s, it was evident that poor fiscal relations and national debt were affecting citizens' abilities to receive health care. Extreme cuts in a number of provincial budgets were leading to major shortcomings in health care delivery such as hospital closures, bed shortages, increased waiting times, reductions in services, and salary caps for specialist physicians (Maioni 2002). Furthermore, Ottawa introduced the Canada Health and Social Transfer (CHST) scheme in 1995, a system that combined cash transfer for social assistance, health, and post-secondary education into a single block fund (Wong 2005). The CHST ultimately replaced the EPF Fund, and obligated the provinces to prioritize funding between other social programs. 
Intergovernmental relationships in regards to health care funding have been characterized by power struggles and assertions of political autonomy. The federal government has assumed entitlement to use its spending powers by setting federally construed health standards over provinces, which have raised numerous political and constitutional concerns (Rocher and Smith 2002). Since the 1977 EPF Act, the federal government has drastically decreased funding for health programs. Cash payments and tax points from the federal government totalled $27.5 \%$ of total provincial health spending in 2001-2, which is a significant reduction from the initial $50 \%$ in the postwar era (Wong 2005). The various changes made to the transfer payment system offer uncertainty to the provincial governments, and hinder their ability to make important long term health care plans. Since long term planning is an essential strategy for optimal health care delivery, citizens may be receiving the short end of the stick due to fluctuating intergovernmental relationships.

\section{Fiscal Imbalance}

Additionally, the existence of vertical and horizontal fiscal imbalance (VFI and HFI, respectively) has spurred health care debates nationwide. Contrary to the opinion of the national government, it is alleged that the federal retrenchment period during the 1990s is the main cause for the VFI. Since then, the provinces have struggled to meet the expenditure requirements, and claim that Ottawa has not fully restored this imbalance. On the other hand, the federal government has been working to address the HFI through equalization payments, in order for the "have-not" provinces to provide reasonable and comparable public health services (Bakvis, Baier and Brown 2009, Lazar 2004).

Though the federal and provincial government have both assumed roles for health care provision, both orders simply have conflicting views of fiscal responsibility. Johnson Redden (2002) clearly summarizes this intergovernmental clash as she states that the provinces focus on autonomy in policymaking and securing funding to adequately provide health care, whereas the federal government are concerned with controlling costs and enforcing national standards. The story of fiscal federalism narrates strained intergovernmental interactions that are mainly correlated with funding concerns. Consequently, the early harmonious relationship of "cooperative federalism" seen in the early postwar period eventually subsided in the 1990 s to a more antagonistic mode of intergovernmental relationships between Ottawa and the provincial governments (Johnson Redden 2002, Wong 2005).

\section{Process versus Outcome}

Although federalism has significantly contributed to the creation of Canadian health care, there have been claims that it can ultimately be ineffective for the system. Are institutional structures preventing Canadian citizens from receiving the finest health care? Johnson Redden (2002) argues that even though federalism has established a set of stable and efficient arrangements, it doesn't contribute to the development of an effective system and may instead undermine its overall effectiveness. She also states that the current intergovernmental framework of Canadian health care is too narrow, as it concentrates on the process of policymaking more than on the policy outcome itself (Johnson \& Redden 2002). Thus, intergovernmental struggles for stability may actually be counterproductive to the foundation of the health system. As a result, federalism imposes limitations to policy flexibility and adaptability, while possibly deterring necessary adjustments to the system. Health care is an ever-changing field that requires constant policy change and innovation. Slow policy updates may be detrimental to the provision of health care to citizens. Moreover, it is possible that intergovernmental concerns have taken priority over health care related issue, which means that proposals for health reforms, improvements, and experimentation may not be receiving sufficient deliberation.

\section{Accountability and Veto Players}

The existence of veto players in the institutional properties of federalism tends to produce difficulties when trying to assert accountability. Alas, Canadians could not identify the order of government that was responsible for the cuts in health spending. Jordan (2009) states that by the year 2000 the decline in health spending became a severe concern, but the complexity of the intergovernmental system and the provincial-federal internal strife rendered it challenging to assess blame and accountability. The inability to hold political actors responsible may possibly lead to a policymaking stalemate, thus slowing down the progression of health care and hindering service delivery to citizens. Likewise, conflicts in the intergovernmental system are detrimental as citizens may ultimately lose faith in the health care system because they do not know to whom they should assess blame. Moreover, Maioni (2002) states that the lack of accountability may lead to a lack of public support, which is damaging to the federation, but also harmful to the quality of citizens' life. 
On the other hand, Rocher and Smith (2002) argue that multiple veto points may provide numerous accessible opportunities for policy change, especially for social forces who seek to influence health policy. At the same time, one must consider all other institutional factors present in Canadian federalism as dynamics like executive federalism may not even be swayed by interest groups. Thus, institutional structures play an important role in policy making and have a noteworthy impact on citizens and their health care system.

\section{The Future of Medicare in Canada}

As we have seen, Canadian federalism brought positive and negative effects to the health care system. While the decentralized federal framework embraced interprovincial diversity to establish health care, it also set limitations on provincial autonomy through national standards of the CHA. How can Canadian federalism contribute to the progression of the health system and move forward from past setbacks to provide excellent care for citizens?

The intergovernmental tensions that have arisen from fiscal disagreements are evidence that there is a need for mechanisms to mediate intergovernmental conflicts. In 1999, the federal and provincial governments (with the exception of Quebec) introduced of the Social Union Framework Agreement (SUFA), which acknowledges the requirement for more transparency and consultation in intergovernmental policymaking to eliminate federal-provincial disparities (Bakvis, Baier and Brown 2009, Fierlbeck 2002, Maioni 2002).

In 2002, a report from the Commission on the Future of Health Care in Canada, known as the Romanow Report, suggested numerous changes, such as a $\$ 15$ billion dollar injection, in order to sustain the Medicare in Canada. It was uncertain if the report would have any policy impact, but the federal government immediately responded with the commitment of $\$ 30$ billion towards health care for the next ten years (Wong 2005). This is quite a sizeable contribution as Wong (2005) affirms that "the total public health spending in 2001-2 amounted to \$74.6 billion". Accordingly, the quick federal response to the Romanow Report indicates an effort towards recovery from ongoing intergovernmental tensions, but also a promising outlook for the future health of Canadian citizens.

\section{Conclusion}

In the past decade, Canadian federalism has made positive and negative contributions to public health care. The decentralized federal framework allowed for provincial policy experimentation, while intergovernmental relationships supported policy expansion. In contrast, the complexity of intergovernmental relationships and the unclear delineation between the roles for both orders of government have caused considerable delays in health care delivery. The controversies of fiscal federalism and fiscal imbalances continue to pose questions about the need for more transparency and accountability within the federation. Furthermore, federal spending powers and their interference in provincial jurisdictions have been a hotly contested issue. Policies like the EPF and the CHA interfere with provincial jurisdictions, and prevent policy experimentation that may lead to revolutionary ideas like the establishment of health care. Though it is important to note that by being an enabler rather than an enforcer, the holistic perspective of the national government can be highly beneficial when envisioning long-term goals. Nevertheless, the current path of health care is heading towards an era of complementary intergovernmental interactions as a result of documents like the Romanow Report. As a result, Canadians should look forward to the development of a more efficient, innovative and reliable public health care system in the near future. 


\section{Bibliography}

Bakvis, Herman, and Grace Skogstad. Canadian Federalism. Toronto: Oxford

University Press,

2008.

Bakvis, Herman, Gerald Baier, and Douglas Brown. Contested Federalism. Toronto: Oxford University Press, 2009.

Fierlbeck, Katherine. "Paying to Play? Government Financing and Health Care Agenda Setting." The Commission on the Future of Health Care in Canada. Ottawa: Government of Canada, 2002. 1-33.

Johnson Redden, Candace. "Health Care Politics and the Intergovernmental Framework in Canada." The Commission on the Future of Health Care in Canada. Ottawa: Government of Canada, 2002. 1-27.

Jordan, Jason. "Federalism and Health Care Cost Containment in Comparative Perspective." The Journal of Federalism 39, no. 1 (2009): 164-186.

Lazar, Harvey. Money, Politics, and Health Care: Reconstructing the FederalProvincial Partnership. Montreal: The Institue for Research on Public Policy, 2004.

Maioni, Antonia. "Roles and Responsibilities in Health Care Policy." The Commission on the Future of Health Care in Canada. Ottawa: Government of Canada, 2002. 1-34.

Rocher, François, and Miriam Smith. "Federalism and Health Care: The Impact of Political-Institutional Dynamics on the Canadian Health Care System." The Commission on the Future of Health Care in Canada. Ottawa: Government of Canada, 2002. 1-37.

Wong, Joseph. "Re-casting Canadian Federalism: Health Care Financing in the New Century." The Reforming Health Social Security. Washington D.C.: World Bank, 2005. 112-124. 